\title{
Analysis of outer membrane vesicle associated proteins isolated from the plant pathogenic bacterium Xanthomonas campestris pv. campestris Vishaldeep K Sidhu ${ }^{\dagger 1}$, Frank-Jörg Vorhölter ${ }^{2}$, Karsten Niehaus ${ }^{1}$ and Steven A Watt*†1
}

Address: ${ }^{1}$ Dep.7 Proteome and Metabolome Research, Faculty of Biology, Bielefeld University, POB 1001 31, D-33501 Bielefeld, Germany and ${ }^{2}$ Center for Biotechnology, Bielefeld University, Universitaetstr. 25, 33615, Bielefeld, Germany

Email: Vishaldeep K Sidhu - Vishaldeep.Kaur.Sidhu@Genetik.Uni-Bielefeld.DE; Frank-Jörg Vorhölter - Frank-Joerg.Vorhoelter@Genetik.UniBielefeld.DE; Karsten Niehaus - Karsten.niehaus@cebitec.de; Steven A Watt* - Steven.Watt@Genetik.UNI-Bielefeld.DE

* Corresponding author †Equal contributors

Published: 2 June 2008

BMC Microbiology 2008, 8:87 doi:10.1 I86/147/-2/80-8-87

This article is available from: http://www.biomedcentral.com/I47|-2/80/8/87

(c) 2008 Sidhu et al; licensee BioMed Central Ltd.

This is an Open Access article distributed under the terms of the Creative Commons Attribution License (http://creativecommons.org/licenses/by/2.0), which permits unrestricted use, distribution, and reproduction in any medium, provided the original work is properly cited.

\begin{abstract}
Background: Outer membrane vesicles (OMVs) are released from the outer membrane of many Gram-negative bacteria. These extracellular compartments are known to transport compounds involved in cell-cell signalling as well as virulence associated proteins, e.g. the cytolysine from enterotoxic E. coli.

Results: We have demonstrated that Xanthomonas campestris pv. campestris (Xcc) releases OMVs into the culture supernatant during growth. A proteome study identified 3 I different proteins that associate with the OMV fraction of which half are virulence-associated. A comparison with the most abundant outer membrane (OM) proteins revealed that some proteins are enriched in the OMV fraction. This may be connected to differences in the LPS composition between the OMVs and the OM. Furthermore, a comparison of the OMV proteomes from two different culture media indicated that the culture conditions have an impact on the protein composition. Interestingly, the proteins that are common to both culture conditions are mainly involved in virulence.
\end{abstract}

Conclusion: Outer membrane vesicles released from the OM of Xcc contain membrane- and virulence-associated proteins. Future experiments will prove whether these structures can serve as "vehicles" for the transport of virulence factors into the host membrane.

\section{Background}

The Gram-negative bacterium Xanthomonas campestris pv. campestris $(\mathrm{Xcc})$ is the causal agent of "black rot" disease in crucifers, which include a number of plants of economical importance. Xanthomonas campestris can be subdivided into different pathovars according to their host range $[1,2]$. Xanthomonads invade compatible host plants via hydathodes, stomata or wound openings. The infection process itself is facilitated by high temperatures and humidity, which are climatic characteristics of a multitude of developing countries in Latin America, Africa and Asia, where Xanthomonas epidemics account for substantial economical losses [2]. To gather a deeper understanding of how these bacteria cause disease in different plants, the genome sequences of four different Xanthomonas pathovars were established [3-5]. Furthermore, 
recent sequencing projects have revealed the genomic information of three different Xanthomonas campestris pv. campestris strains $[3,6,7]$. This plethora of genomic information is a useful resource to identify genes involved in host specific pathogenicity and in more general virulence mechanisms. The specific host range determining mechanisms are orchestrated by the fine tuned interaction of pathogen derived effector proteins and structures within the host cell $[8,9]$. These proteins are commonly directly delivered into the host cell by the type-III secretion system (TTSS), which is highly conserved among Gram-negative pathogens. The components of the TTSS are usually encoded by the so-called $h r p$-operon (hypersensitive response and pathogenicity), which consists of approximately 20 genes, of which nine are highly conserved and therefore termed $h r c$ [9]. The transcription of the hrp-genes is tightly controlled and only activated in environments that resemble the host [10]. One of the key proteins of the TTSS is the HrpF pore, which is inserted into the host's plasma membrane and enables the pathogen to channel effector proteins into the host cell $[11,12]$. General virulence mechanisms involve proteins responsible for trace element acquisition (e.g., iron), extracellular proteins with lytic functions as well as protein complexes involved in their secretion [13-15]. These proteins aid the colonization of the host and a saprophytic lifestyle in later stages of disease.

Only recently, the role of outer membrane derived vesicles, so-called outer membrane vesicles (OMVs), have been studied in detail. They have been found to act as vehicles for the transport of virulence associated compounds into other cells [16-18]. OMVs are known to be constantly liberated from the outer membrane of most Gram-negative bacteria [19]. It has been demonstrated that they contain outer membrane and periplasmic proteins and in some cases DNA or cell-cell signalling molecules $[20,21]$. This makes OMVs an ideal structure to transport hydrophobic compounds like membrane proteins into the host. The best-studied membrane anchored virulence factor is the ClyA protein from enterotoxic bacterium E. coli, which forms pores inside the host membrane and thus causes lysis. It has been demonstrated that ClyA is inserted into the outer membrane of the pathogen as inactive monomers, which are then released and embedded in OMVs where they are converted into an active form that assembles into the multimeric membrane pore. Upon fusion of the OMV with the host membrane a functional ClyA pore is inserted [16]. This clearly indicates the potential of OMVs to deliver membrane active virulence factors into the host.

In this study, we present the proteome of OMVs isolated from the culture supernatant of the Xcc strain B100. Furthermore, we could demonstrate that the composition of the OMV proteome differs from that of the outer membrane implying some kind of protein sorting mechanism. A considerable amount of proteins identified in the OMV fraction are assigned virulence factors or are connected to effector protein transport indicative of the probable involvement of OMVs as vehicles for these compounds.

\section{Results \\ OMVs are released from the outer membrane of Xcc during growth}

Electron microscopy of an OMV fraction isolated from the culture supernatant of M9 minimal medium was performed to determine whether $X c c$ releases OMVs into the medium and to test the applicability of the purification method. The electron micrographs of negatively stained outer membrane vesicles mounted on glow-discharged carbon-coated nickel grids indicate that most vesicles have a spherical shape. A few dented vesicles can also be observed (Fig. 1A). The dents may be a result of dehydration, which occurs during the preparation of the vesicles. The vesicle diameters range from 10 to $100 \mathrm{~nm}$ with an average diameter of $45 \pm 21 \mathrm{~nm}(\mathrm{n}=373)$. Immunogoldlabeling of whole cell and vesicle preparations was performed using an anti-Xcc antibody [22]. As displayed in Fig. $1 \mathrm{~B}$ and $1 \mathrm{C}$, the antibody specifically recognized the Xcc cells and thus Xanthomonas surface-derived compounds in the OMVs. Furthermore, a lipopolysaccharide (LPS)-specific SDS-PAGE was performed to compare the LPS composition of whole cell preparations to that of the OMVs (Fig. 2). The lanes on the gel loaded with the crude LPS preparation and the hot-phenol purified sample displayed bands representing LPS (consisting of O-antigen, the core region and lipid-A), the core attached to lipid-A and free lipid-A. The bands located between the core and LPS represent LPS synthesis intermediates consisting of the core and different amounts of oligo-saccaride subunits. The lane loaded with the OMV sample only displays a band representing the mature LPS structure and free lipid-A. This indicates that the OMVs are derived from the outer membrane and more interestingly only contain mature LPS whilst the whole cell preparations also contain intermediates of the LPS biosynthesis.

\section{The OMV proteome of Xcc contains outer membrane and virulence-associated proteins}

To analyse its protein cargo, the OMV fraction was harvested from the cell-free culture supernatant of M9 cultures and subjected to SDS-PAGE. Previous attempts to resolve the OMV protein fraction using two-dimonesional gel electrophoresis failed due to the high amount of exopolysaccharides that are co-purified with the vesicles. Another problem was the low amount of proteins (30 $\mu \mathrm{g} \cdot \mathrm{mL}^{-1}$ ) that could be purified from o litre of culture supernatant, which prohibited further purification steps. Therefore, a combination of SDS-PAGE and nano-LC-ESI- 


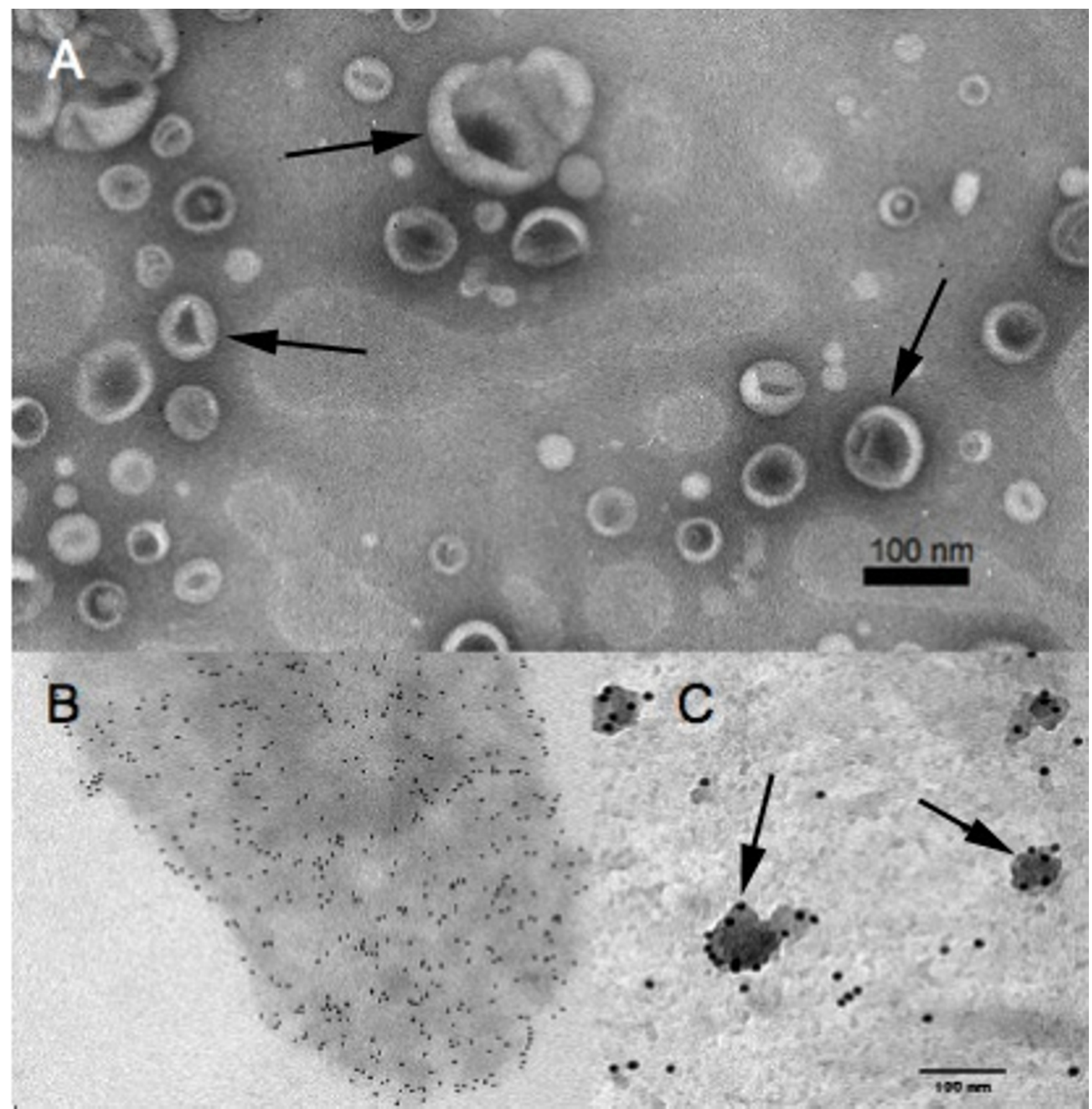

\section{Figure I}

Electron micrgraphes of Xcc cell and OMV preparations. (A) Electron micrograph of I\% (w/v) uranyl acetate stained outer membrane vesicles extracted from the cell free supernatant of Xanthomonas campestris pv campestris strain BI00 at a 30 $\mathrm{k}$ fold magnification (OMVs highlighted by arrows). (B) Immunogold electron microscopy of $\mathrm{I} \%$ (w/v) uranyl acetate stained $X c c$ cell at $14 \mathrm{k}$ fold magnification after incubation with an anti-XccB I00 antibody which was detected by a $10 \mathrm{~nm}$ gold particle bound to a goat anti-rabbit antibody (gold-labelled OMV highlighted by arrows). (C) Immunogold electron micrograph of I\% $(\mathrm{w} / \mathrm{v})$ uranyl acetate stained OMVs at $27 \mathrm{k}$ fold magnification after incubation with an anti-XccB I00 antibody detected with a 10 $\mathrm{nm}$ gold particle bound to an goat anti-rabbit antibody. 


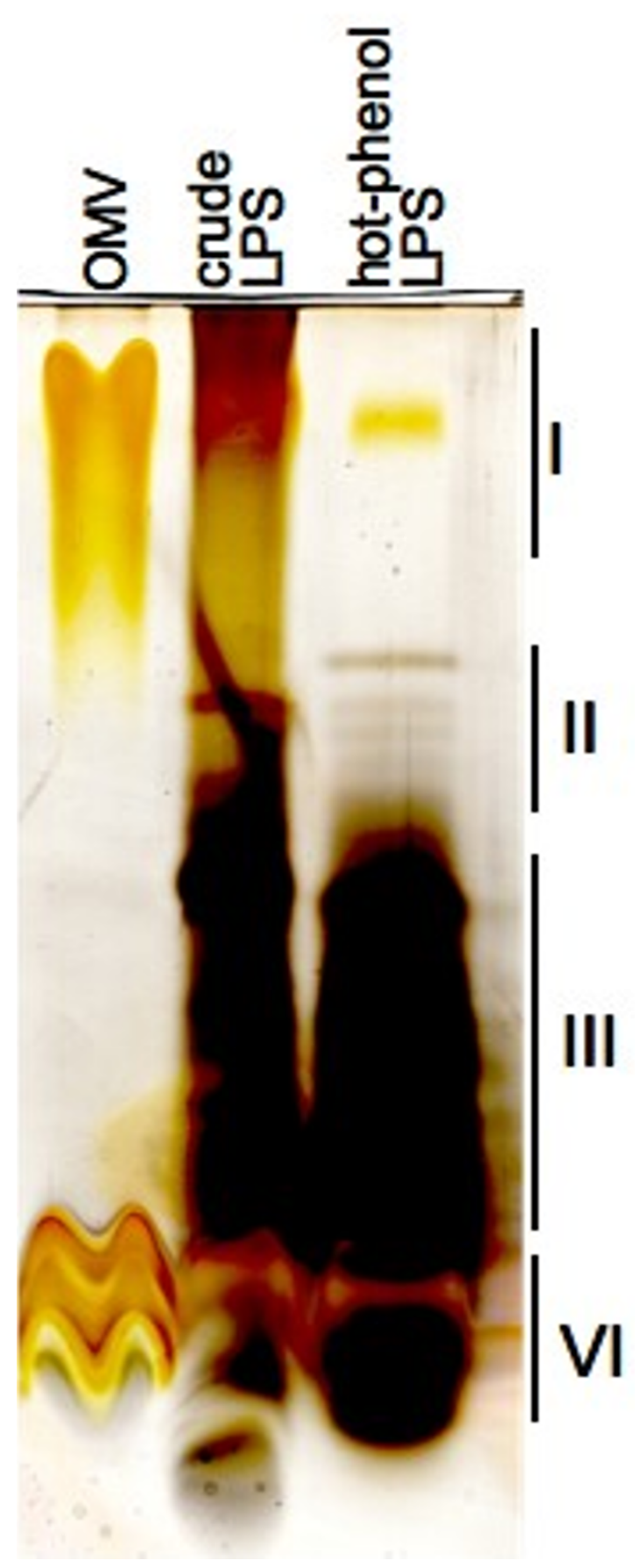

Figure 2

SDS-PAGE performed with LPS from OMVs and whole cell preparations. The OMVs as well as a crude and a hot-phenol purified LPS preparation were separated on an SDS-PAGE and stained with an LPS-specific silver stain. The gel displays different bands resembling: (I) mature LPS consisting of the $\mathrm{O}$-antigen, the core region attached to lipid-A; (II) LPS biosynthesis intermediates with incomplete O-antigen; (III) Lipid A attached to the core region; (VI) free lipid-A structure.
MS/MS of tryptically-digested gel-sections was employed to identify the proteins that associate with the OMV fraction. This method has been described previously for various membrane proteome studies $[42,43]$. The resulting Coomassie stained SDS-PAGE revealed approximately 15 protein bands, which were excised in vertical sections comprising 2-6 protein bands per section for subsequent trypsin digestion (Fig. 3A). The trypsin-generated peptide masses, as well as their fragment ions were determined by nano-LC-ESI-MS/MS. This data was the basis for a MASCOT aided database query, which led to the identification of 31 different proteins (Table 1 additional MS/MS data is presented in Table 4 in Additional file 1). A query result was only considered as significant if the overall score was higher than 25, more than two tryptic peptides as well as their fragment ions matched to the protein in question and the calculated molecular weight fitted to the initial gel section. To verify the ESI-MS/MS results, individual protein bands were excised from the SDS-PAGE and treated as already described. The tryptic peptides were analysed using a MALDI-TOF-MS approach and the resulting peptide mass fingerprints were used for a MASCOT aided database query. In this approach, only scores higher that 49 were considered significant. Only seven proteins could not be verified using the MALDI-TOF-MS approach (FadL, Ffh, AvrBs2, XynB, RlpA, RlpB, Lipoprotein precursor). They can also be considered as "insecure" candidates also because their MASCOT-significance scores are close the threshold (Table 1). Three proteins, HrcU, OmpA and OmpW3, could be identified in more than one gel section. Since they were in neighbouring sections, it can be assumed that they originate from protein bands, which were located in the section border. According to the function or cellular localization it was possible to cluster the proteins into 7 groups (Fig. 4). Five of these groups consider the localization of the proteins within the cell and were termed "cytosol", "inner membrane", "periplasm", "outer membrane" and "exported". The remaining two groups harbour proteins involved in virulence, including "virulence factors" and proteins of the "type-III secretion" system (Fig. 4A, B). The two major protein groups in the OMV proteome of M9 cultivated Xcc cells associate with the "outer membrane" (36\%), its majority being TonBdependent receptor proteins, and the virulence-associated group (42\%), which consists of "virulence factors" and "type-III associated" proteins. The virulence-associated group does not only consist of the membrane attached Hrc, Hrp (23\%) and HrpF proteins but also of "virulence factors" (19\%) consisting of avirulence proteins and two cell wall degrading enzymes, a cellulase (Egl) and a xylosidase (XynB). Furthermore, the OMVs contain 13\% periplasmic proteins, which may be entrapped in the vesicle lumen during their releases from the outer membrane. A software-aided analysis of the C-termini of all identified proteins revealed that $39 \%$ have a putative secretion sig- 
Table I: Proteins identified in the OMV fraction of cultures grown in M9 medium.

\begin{tabular}{|c|c|c|c|c|c|c|c|c|}
\hline Section & Protein & Acc. No. & MW(cal) & Size range & $\begin{array}{c}\text { Coverage } \\
\text { (ESI-MS/MS) }\end{array}$ & $\begin{array}{l}\text { Score (ESI- } \\
\text { MS/MS) }\end{array}$ & $\begin{array}{l}\text { Coverage } \\
\text { (MALDI) }\end{array}$ & $\begin{array}{c}\text { Score } \\
\text { (MALDI) }\end{array}$ \\
\hline \multirow[t]{8}{*}{ I } & $\begin{array}{l}\text { TonB-dependent } \\
\text { receptor with signalP }\end{array}$ & AAM 42139 & 100858 & $80-150$ & 10 & 162 & 31 & 134 \\
\hline & $\begin{array}{l}\text { Outer membrane } \\
\text { protein With signalP }\end{array}$ & AAM40663 & 90600 & & 6 & 113 & 27 & 96 \\
\hline & $\begin{array}{l}\text { Oar putative outer } \\
\text { membrane receptor } \\
\text { protein, tonB- } \\
\text { dependent with signalP }\end{array}$ & AAM4177I & 117723 & & 4 & 91 & 11 & 86 \\
\hline & $\begin{array}{l}\text { TonB-dependent outer } \\
\text { membrane receptor }\end{array}$ & AAM4I663 & 91909 & & 6 & 49 & 9 & 89 \\
\hline & $\begin{array}{l}\text { FpvA TonB- } \\
\text { dependent outer } \\
\text { membrane } \\
\text { ferripyoverdine } \\
\text { receptor with signalP }\end{array}$ & AAM42628 & 81083 & & 6 & 59 & 8 & 60 \\
\hline & $\operatorname{HrcV}(\mathrm{HrcV})$ & AAM40527 & 69015 & & 9 & 32 & 12 & 54 \\
\hline & HrpF (HrpF protein) & AAM405I5 & 98836 & & 11 & 30 & 19 & 92 \\
\hline & $\begin{array}{l}\text { AcrD Outer } \\
\text { membrane efflux } \\
\text { protein }\end{array}$ & AAM4I427 & 130193 & & 8 & 27 & 11 & 102 \\
\hline \multirow[t]{6}{*}{2} & $\begin{array}{l}\text { FadL outer } \\
\text { membrane fatty acid } \\
\text { porin with signalP }\end{array}$ & AAM39336 & 47455 & $60-80$ & 13 & 235 & - & - \\
\hline & $\begin{array}{l}\text { Egl exported cellulase } \\
\text { with signalP }\end{array}$ & AAM4279I & 52209 & & 7 & 140 & 18 & 88 \\
\hline & $\begin{array}{l}\text { Avirulence protein } \\
\text { with signalP }\end{array}$ & AAM43445 & 67281 & & 5 & 27 & 9 & 59 \\
\hline & HrcN HrcN protein & AAM40534 & 47759 & & 5 & 30 & 7 & 52 \\
\hline & $\begin{array}{l}\text { ffh Signal recognition } \\
\text { particle protein }\end{array}$ & AAM40492 & 49312 & & 7 & 27 & - & - \\
\hline & $\begin{array}{l}\text { AvrBs2 (avirulence } \\
\text { protein) }\end{array}$ & AAM3937I & $7847 \mid$ & & 3 & 27 & - & - \\
\hline \multirow[t]{4}{*}{3} & $\begin{array}{l}\text { OmpA family outer } \\
\text { membrane protein } \\
\text { with signalP }\end{array}$ & AAM40245 & 39338 & $40-60$ & 27 & 405 & 21 & 143 \\
\hline & $\begin{array}{l}\text { AvrBsI avirulence } \\
\text { protein AvrBsI }\end{array}$ & AAM4I 388 & 49789 & & 6 & 29 & 8 & 61 \\
\hline & $\begin{array}{l}\text { XynB exported xylan } \\
\text { I,4-beta-xylosidase } \\
\text { with signalP }\end{array}$ & AAM43196 & 58311 & & 3 & 32 & - & - \\
\hline & HrcU HrcU protein & AAM40528 & 38694 & & 6 & 27 & 6 & 57 \\
\hline \multirow[t]{5}{*}{4} & $\begin{array}{l}\text { OmpA family outer } \\
\text { membrane protein } \\
\text { with signalP }\end{array}$ & AAM40245 & 39338 & $30-40$ & 32 & 402 & 19 & 96 \\
\hline & VirB6 protein & AAM4257I & 38386 & & 6 & 32 & 5 & 56 \\
\hline & Hrc $\mathbf{U} \mathrm{HrcU}$ protein & AAM40528 & 38694 & & 8 & 30 & 8 & 58 \\
\hline & $\begin{array}{l}\text { RIpA Exported rare } \\
\text { lipoprotein A With } \\
\text { signalP }\end{array}$ & AAM42727 & 46235 & & 6 & 35 & - & - \\
\hline & $\begin{array}{l}\text { HrpW* } \\
\text { protein) }\end{array}$ & AAM405I7 & 33372 & & 2 & 28 & 11 & 59 \\
\hline \multirow[t]{2}{*}{5} & $\begin{array}{l}\text { Putative exported } \\
\text { protein }\end{array}$ & AAM40085 & 35080 & $25-30$ & 8 & 53 & 9 & 68 \\
\hline & $\begin{array}{l}\text { OmpW3 OmpW } \\
\text { family outer membrane } \\
\text { protein }\end{array}$ & AAM4279I & 23494 & & 7 & 41 & 10 & 63 \\
\hline
\end{tabular}


Table I: Proteins identified in the OMV fraction of cultures grown in M9 medium. (Continued)

\begin{tabular}{|c|c|c|c|c|c|c|c|c|}
\hline & $\begin{array}{l}\text { *RIpB Rare } \\
\text { lipoprotein B with } \\
\text { signalP }\end{array}$ & AAM40532 & 22959 & & 10 & 31 & - & - \\
\hline & $\begin{array}{l}\text { Lipoprotein precursor } \\
\text { with signalP }\end{array}$ & AAM4I856 & 26209 & & 4 & 26 & - & - \\
\hline \multirow[t]{3}{*}{6} & $\begin{array}{l}\text { OmpW3 OmpW } \\
\text { family outer membrane } \\
\text { protein }\end{array}$ & AAM4279I & 23494 & $20-25$ & 8 & 58 & 10 & 72 \\
\hline & HrpB4 HrpB4 protein & AAM40532 & 22919 & & 4 & 29 & 4 & 52 \\
\hline & $\begin{array}{l}\text { HpaH Putative } \\
\text { transglycosylase } \mathrm{HpaH}\end{array}$ & AAM40539 & 21109 & & 3 & 29 & 6 & 58 \\
\hline \multirow[t]{4}{*}{7} & $\begin{array}{l}\text { Putative exported } \\
\text { protein with signalP }\end{array}$ & AAM40594 & 10647 & $15-20$ & 15 & $|7|$ & 22 & 127 \\
\hline & $\begin{array}{l}\text { XpsH General } \\
\text { secretion pathway } \\
\text { protein }\end{array}$ & AAM39979 & 18208 & & 20 & 47 & 17 & 61 \\
\hline & $\begin{array}{l}\text { UptD outer } \\
\text { membrane protein } \\
\text { with signalP }\end{array}$ & AAM39910 & 17116 & & 15 & 39 & 18 & 83 \\
\hline & HrpE HrpE protein & AAM405I9 & 9749 & & 30 & 30 & 32 & 56 \\
\hline
\end{tabular}

The section indicates the gel-section excised from the corresponding SDS-PAGE. The values indicated under MW(cal) gives the calculated molecular weight of the identified proteins. The size range relates the excised gel-section with regard to the molecular weight standard on the SDSPAGE. Score (MOWSE-score) and coverage (sequence coverage) relate to the two approaches (ESI-MS/MS or MALDI-TOF-MS) utilized for the identification of the proteins on the SDS-PAGE.

nal, which makes them targets for the general secretion pathway.

In summary, the proteome of the OMVs mainly consists of proteins associated to the outer membrane and proteins either located in the periplasm or travelling through it.

\section{OMVs do not contain all high abundant proteins present in the OM proteome}

A comparison of the proteins extracted from OMVs and the outer membrane (OM) was conducted to analyse if there is a preference for certain proteins to be located in the OMVs. The outer membrane fraction was also separated by SDS-PAGE and sectioned as already described (Fig. 3B). Each gel section was digested with trypsin and analysed by nano-LC-ESI-MS/MS. The comparison of the SDS-PAGE patterns of the OMV and OM proteome revealed a clear difference between the two proteomes (Fig. 3B). The MASCOT software-aided database query using the ESI-MS/MS data resulted in the significant identification of 26 different proteins (Table 2 additional MS/ MS data is presented in Table 5 in Additional file 1). This number clearly does not reflect the exact number of proteins present in the OM fraction but rather stands for the most abundant proteins in each gel section. The OM protein preparation contains 15 different outer membrane proteins, most of them being TonB-dependent receptors (9). Since most of these 15 proteins have probability scores above 200 it can be presumed, that they belong to the group of high abundant outer membrane proteins.
Interestingly, only half of these proteins are also present in the OMV protein fraction. There are five further outer membrane proteins with probability scores greater than 140 that can only be identified in the OM proteome. Furthermore, only three of the nine TonB-dependent receptors can be found in both protein preparations. The OM protein fraction revealed 11 non-outer membrane proteins, among those are six secreted, four inner membraneassociated and one cytosolic (TufA) protein. The inner membrane-associated proteins are co-purified with the outer membrane, since the ultrasonification process will also liberate inner membrane fragments. The secreted proteins could be co-purified whilst they are associated with one of the membranes during the secretion process. Among this class of non-outer membrane proteins are three that could be identified in the OM and OMV fraction alike (Egl, Ffh, XpsH). Only two proteins, a cellulase (Egl) and a $\beta$-glucosidase ( $\mathrm{Bgl})$, could be assigned as virulence factors. Surprisingly, no type-III secretion-associated proteins, which are present in abundance in the OMV proteome, are among the identified in the OM fraction.

Although the OMVs originate from the outer membrane only less than half of the most abundant OM proteins could also be identified in the OMV fraction. Noteworthy is that all but one of the virulence associated proteins of the OMVs are among the high abundant proteins of the outer membrane. Therefore, 21 proteins, most of them virulence-associated, seem to be enriched in the OMV fraction. 

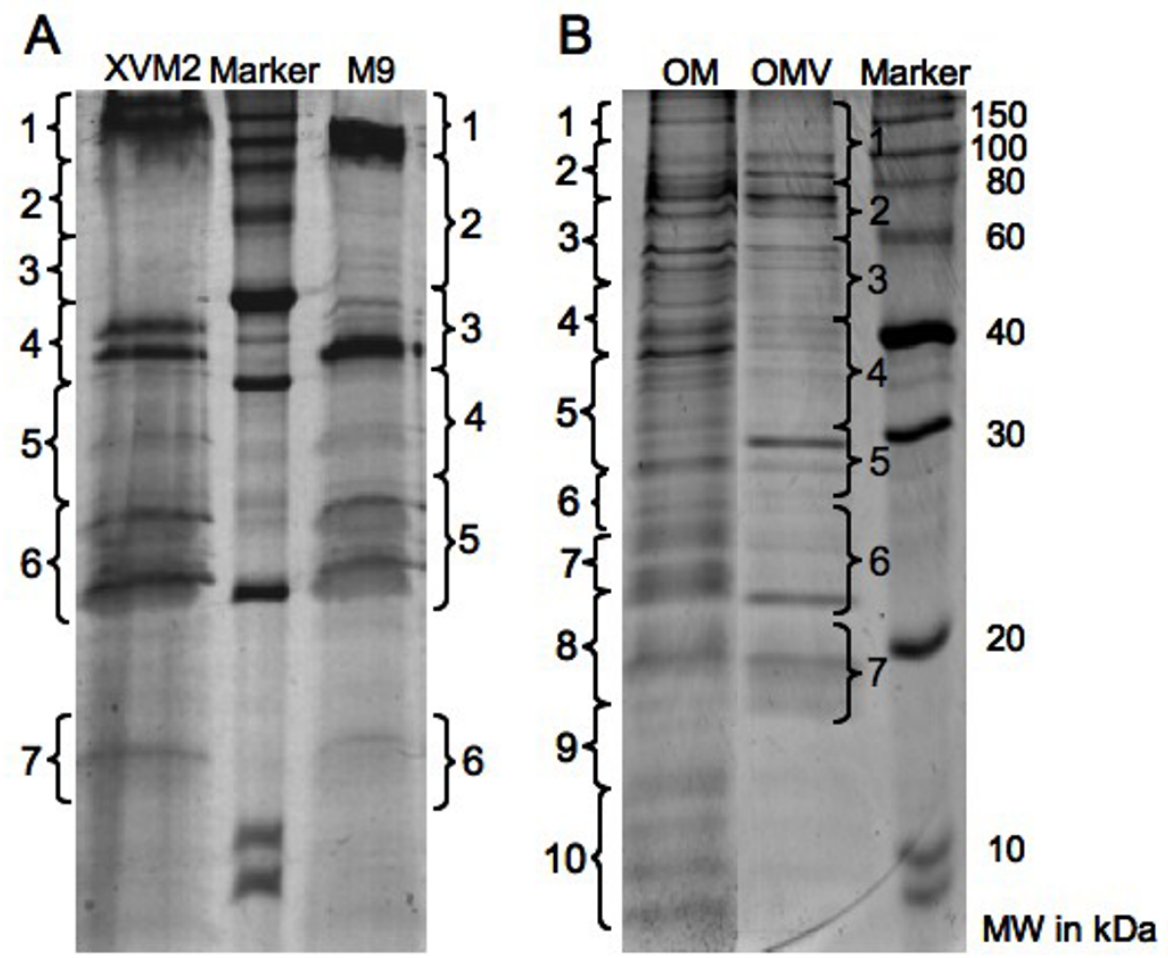

Figure 3

SDS-PAGE of proteins extracted from OMVs of different culture conditions and the outer membrane. (A) $A$ I $2 \%$ acrylamide SDS-PAGE performed with proteins obtained from OMVs of Xcc cultures grown in M9 and XVM2 medium. The brackets with numeration indicate the sections taken from the gel for tryptic digestion. (B) Protein profiles of OMVs isolated from cultures grown in $M 9$ medium and the outer membrane (OM) fraction prepared from the same culture.

\section{The growth medium has an influence on the OMV protein composition}

The XVM2 medium, which is known to induce genes coding for the type-III secretion system and virulence factors [27], was used to study the influence of growth conditions on the OMV proteome. The OMV proteins isolated from $\mathrm{XVM} 2$ cultures were treated as already described. This procedure led to the identification of 23 different proteins using the LC-ESI-MS/MS approach (Table 3 additional MS/MS data is presented in Table 6 in Additional file 1). The MALDI-TOF-MS approach could verify the identity of all but five proteins (XadA1, AvrBs1, FasD, FadL, XynB). These proteins can be regarded as "insecure" identifications. Nonetheless, $50 \%$ of the identified proteins belong to the group "outer membrane". Most (9) of them are also present in the proteomes of the OM and OMVs isolated from M9 cultures. Furthermore, seven proteins could only be identified in the OMV fractions isolated from both culture conditions; these include three type-III secretionassociated proteins ( $\mathrm{HrpF}, \mathrm{HrcU}, \mathrm{HrpB} 4)$, three virulence factors (AvrBs2, AvrBs1, XynB) and only one additional protein that is not involved in virulence $(\mathrm{XpsH})$. Another 6 proteins are unique to OMVs of the XVM2 culture. One of these proteins is $\mathrm{HrpXv}$, the regulator of the type-III secretion system, which might be induced by the culture condition. How this protein associates with the OMV fraction, however, is unclear. A noteworthy protein, which also belongs to the unique proteins, is the adhesion protein XadA1, which might be co-regulated with the hrp-regulon. The OMVs isolated from M9 medium contain 14 unique proteins. Interestingly, 4 of these proteins belong to the type-III secretion system ( $\mathrm{HrcV}, \mathrm{HrcN}, \mathrm{HrpW}$, HrpE), which should not be induced under this culture condition. Also noteworthy are 3 lipoproteins, which are exclusive to OMVs from the M9 culture. This indicates that the growth medium has a clear influence on the protein composition of the OMVs. However, 9 proteins can be regarded as the core-proteome. They reflect the outer membrane origin of the OMVs, since they are also among the most abundant OM proteins. The 7 proteins common to OMVs isolated from both media seem to be characteristic for the OMV proteome and a majority of them are involved in virulence. 

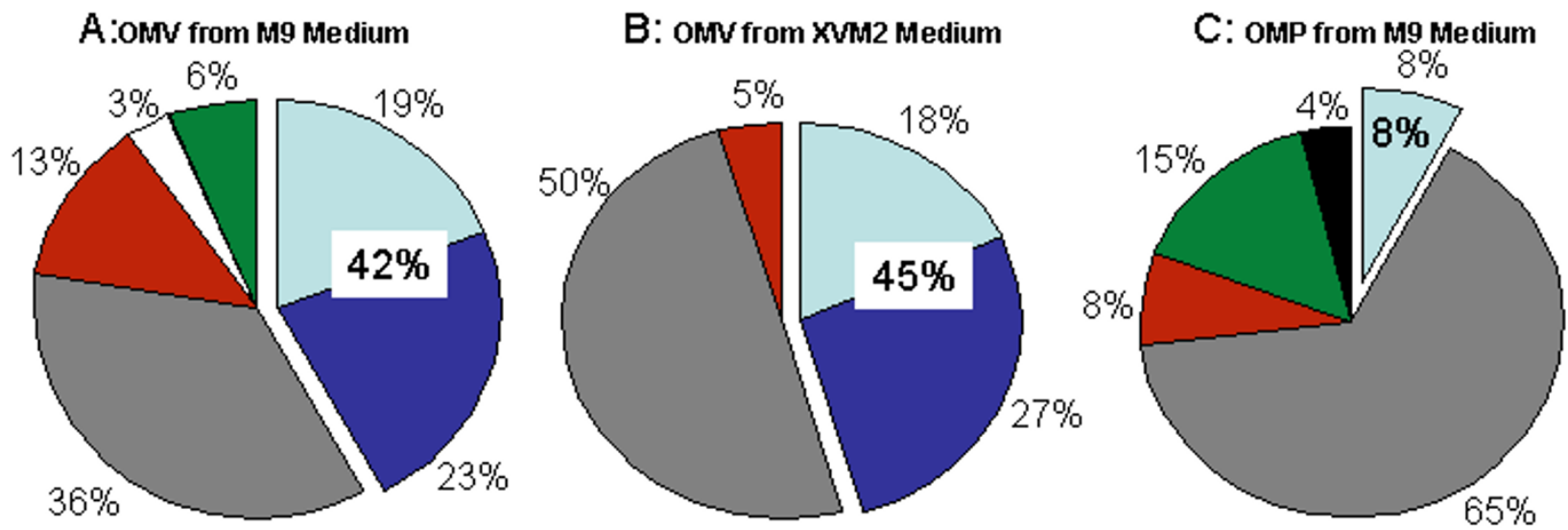

virulence factors
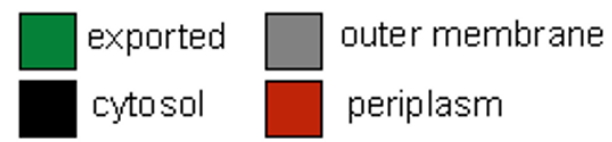

inner membrane

type-III secretion

cytosol

periplasm

\section{Figure 4}

Pie charts of the protein groups found in the OMVand the OM preparations. The proteins identified from OMVs and OMPs were sub-divided into seven groups according to their proposed sub-cellular location or function. The pie charts indicate the number of proteins in each group isolated from OMVs collected from M9 medium (A) from XVM2 medium (B) and the outer membrane proteins isolated from cells grown in M9 medium (C). The percentage values within the pie chart give the amount of proteins grouped as virulence-associated, which comprise the groups of virulence factors and type III secretion proteins.

\section{Discussion \\ Outer membrane vesicles are released from the bacterial surface and contribute membrane proteins to the extracellular proteome}

Previous work of our group describes a comprehensive study of the extracellular proteome of Xanthomonas campestris pv. campestris. There we identified some outer membrane proteins among the most abundant extracellular proteins (OmpA family protein AAM40245; OmpW AAM39855; TonB-dependent receptor AAM42139) [16]. Since outer membrane vesicles (OMVs) are known to be constantly liberated from the outer membrane of Gramnegative bacteria, we suspected that OMVs could be the source of outer membrane proteins in the culture supernatant $[23,19]$. Thus we first employed electron microscopy to demonstrate that Xanthomonas campestris pv. campestris strain B100 releases outer membrane vesicles. The OMV proteome revealed that the outer membrane proteins found in the extracellular proteome are also present here. Furthermore, two other proteins could be identified in both proteomes, the cellulase Egl (AAM42791) and a putative secreted protein (AAM40085). This indicates that OMVs contribute to the extracellular proteome by releasing outer membrane proteins into the environment. Outer membrane vesicles of other Gram-negative bacteria have been described to contain outer membrane proteins, periplasmic proteins, lipopolysaccharides, phospholipids, DNA, toxins and other factors associated with virulence [23,20,21]. Previous studies have demonstrated that bacterial OMVs can interact with membranes of other Gram-negative and Gram-positive bacteria, which can result in lysis of the target organism [25]. Furthermore, Wai and co-workers [16] could demonstrate that OMVs can even deliver toxins into the membrane of a eukaryotic host cell.

Electron micrographs demonstrate that vesicles produced by Xcc are spherical with a diameter ranging between 10 and $100 \mathrm{~nm}$ with a mean diameter of $45 \mathrm{~nm}$. These OMVs are much smaller than those described for mammalian pathogens, e.g., enterotoxic E. coli or Helicobacter pylori, which have diameters ranging up to $300 \mathrm{~nm}[26,19]$. The reduced OMV size could be an adaptation towards the plant cell wall, which does not permit the passage of large structures. Immunogold electron microscopy with Xcc surface-specific polyclonal antibodies indicates that the OMVs are released from the surface of Xanthomonas cells and therefore originate from the outer membrane. The LPS-specific SDS-PAGE confirms this finding, indicating that the OMVs contain LPS. Interestingly, however, they 
Table 2: Proteins identified in the outer membrane fraction of cultures grown in M9 medium.

\begin{tabular}{|c|c|c|c|c|c|c|c|c|}
\hline Section & Protein & Acc.No. & MW(cal) & Size range & $\begin{array}{l}\text { Coverage } \\
\text { (ESI-MS/MS) }\end{array}$ & $\begin{array}{l}\text { Score (ESI- } \\
\text { MS/MS) }\end{array}$ & $\begin{array}{l}\text { Coverage } \\
\text { (MALDI) }\end{array}$ & $\begin{array}{l}\text { Score } \\
\text { (MALDI) }\end{array}$ \\
\hline \multirow[t]{5}{*}{ I } & $\begin{array}{l}\text { TonB-dependent outer } \\
\text { membrane receptor } \\
\text { with signalP }\end{array}$ & AAM 42139 & 100858 & $100-150$ & 19 & 664 & 114 & 16 \\
\hline & $\begin{array}{l}\text { Oar putative outer } \\
\text { membrane receptor } \\
\text { protein, tonB- } \\
\text { dependent with signalP }\end{array}$ & AAM4I77I & 117723 & & 10 & 295 & 64 & 12 \\
\hline & $\begin{array}{l}\text { TonB-dependent outer } \\
\text { membrane receptor } \\
\text { (C-terminal fragment) } \\
\text { with signalP }\end{array}$ & AAM43353 & 110414 & & 8 & 271 & 65 & 6 \\
\hline & $\begin{array}{l}\text { TonB-dependent outer } \\
\text { membrane receptor } \\
\text { (C-terminal fragment) } \\
\text { with signalP }\end{array}$ & AAM4243I & 106797 & & 7 & $|4|$ & - & - \\
\hline & $\begin{array}{l}\text { TonB-dependent outer } \\
\text { membrane receptor } \\
\text { with signalP }\end{array}$ & AAM42675 & 103487 & & 3 & 53 & 57 & 5 \\
\hline \multirow[t]{7}{*}{2} & $\begin{array}{l}\text { TonB-dependent outer } \\
\text { membrane receptor } \\
\text { with signalP }\end{array}$ & AAM42I39 & 100858 & $80-100$ & 14 & 630 & 124 & 18 \\
\hline & $\begin{array}{l}\text { TonB-dependent outer } \\
\text { membrane receptor } \\
\text { with signalP }\end{array}$ & AAM42044 & 83577 & & 21 & 628 & - & - \\
\hline & $\begin{array}{l}\text { FpvA TonB- } \\
\text { dependent } \\
\text { ferripyoverdine } \\
\text { receptor precursor } \\
\text { with signalP }\end{array}$ & AAM42628 & 81083 & & 20 & 506 & 116 & 16 \\
\hline & $\begin{array}{l}\text { PhuR outer } \\
\text { membrane hemin } \\
\text { receptor, tonB- } \\
\text { dependent with signalP }\end{array}$ & AAM4I930 & 85127 & & 17 & 317 & 92 & 13 \\
\hline & $\begin{array}{l}\text { TonB-dependent outer } \\
\text { membrane receptor } \\
\text { with signalP }\end{array}$ & AAM423I6 & 84374 & & 8 & 218 & 64 & 8 \\
\hline & $\begin{array}{l}\text { Outer membrane } \\
\text { protein with signalP }\end{array}$ & AAM40663 & 90600 & & 6 & 113 & 72 & 8 \\
\hline & $\begin{array}{l}\text { Bgl exported beta- } \\
\text { glucosidase with } \\
\text { signalP }\end{array}$ & AAM4I065 & 91830 & & 4 & 34 & - & - \\
\hline \multirow[t]{3}{*}{3} & $\begin{array}{l}\text { Egl exported cellulose } \\
\text { with signalP }\end{array}$ & AAM4279I & 52209 & $50-80$ & 7 & 142 & 68 & 6 \\
\hline & $\begin{array}{l}\text { OmpA family outer } \\
\text { membrane protein } \\
\text { with signalP }\end{array}$ & AAM40245 & 39338 & & 8 & 98 & 72 & 16 \\
\hline & $\begin{array}{l}\text { Ffh Signal recognition } \\
\text { particle protein }\end{array}$ & AAM40492 & 49312 & & 6 & 31 & - & - \\
\hline \multirow[t]{3}{*}{4} & $\begin{array}{l}\text { OmpA family outer } \\
\text { membrane protein } \\
\text { with signalP }\end{array}$ & AAM40245 & 39338 & $40-50$ & 34 & 581 & 18 & 93 \\
\hline & $\begin{array}{l}\text { FadL outer } \\
\text { membrane fatty acid } \\
\text { porin with signalP }\end{array}$ & AAM39336 & 47455 & & 11 & 229 & - & - \\
\hline & $\begin{array}{l}\text { TufA (elongation } \\
\text { factor Tu) }\end{array}$ & AAM40I9I & 43181 & & 14 & 70 & 88 & 12 \\
\hline
\end{tabular}


Table 2: Proteins identified in the outer membrane fraction of cultures grown in M9 medium. (Continued)

\begin{tabular}{|c|c|c|c|c|c|c|c|c|}
\hline \multirow[t]{5}{*}{5} & $\begin{array}{l}\text { OmpA family outer } \\
\text { membrane protein } \\
\text { with signalP }\end{array}$ & AAM40245 & 39338 & $30-40$ & 32 & 402 & 73 & 16 \\
\hline & $\begin{array}{l}\text { Putative secreted } \\
\text { protein }\end{array}$ & AAM39862 & 29865 & & 5 & 41 & 63 & 9 \\
\hline & Egl exported cellulose & AAM4279I & 52209 & & 8 & 39 & 55 & 6 \\
\hline & $\begin{array}{l}\text { XpsE Type II } \\
\text { secretory pathway } \\
\text { ATPase }\end{array}$ & AAM39976 & 64291 & & 3 & 29 & - & - \\
\hline & $\begin{array}{l}\text { FliC Flagellin A } \\
\text { (Flagellin core protein) }\end{array}$ & AAM4I230 & 40380 & & 3 & 29 & 64 & 8 \\
\hline \multirow[t]{3}{*}{6} & $\begin{array}{l}\text { OmpA family outer } \\
\text { membrane protein } \\
\text { with signalP }\end{array}$ & AAM40245 & 39338 & $27-30$ & 29 & 515 & 92 & 18 \\
\hline & $\begin{array}{l}\text { Putative secreted } \\
\text { protein }\end{array}$ & AAM39862 & 29865 & & 3 & 40 & 56 & 8 \\
\hline & $\begin{array}{l}\text { FadL (outer } \\
\text { membrane fatty acid } \\
\text { porin) }\end{array}$ & AAM39336 & $47 \mid 14$ & & 3 & 26 & - & - \\
\hline \multirow[t]{3}{*}{7} & $\begin{array}{l}\text { OmpA family outer } \\
\text { membrane protein } \\
\text { with signalP }\end{array}$ & AAM40245 & 39338 & $24-27$ & 9 & 88 & 73 & 16 \\
\hline & $\begin{array}{l}\text { Putative exported } \\
\text { protein }\end{array}$ & AAM40085 & 35080 & & 8 & 60 & 63 & 12 \\
\hline & $\begin{array}{l}\text { UptE Outer } \\
\text { membrane protein } \\
\text { with signalP }\end{array}$ & AAM399II & 31591 & & 26 & 37 & 73 & 32 \\
\hline \multirow[t]{3}{*}{8} & $\begin{array}{l}\text { OmpW3 ompW } \\
\text { family outer } \\
\text { membrane protein }\end{array}$ & AAM39855 & 23494 & $20-24$ & 7 & 55 & 58 & 13 \\
\hline & $\begin{array}{l}\text { XpsH General } \\
\text { secretion pathway } \\
\text { protein }\end{array}$ & AAM39979 & 18208 & & II & 47 & 63 & 21 \\
\hline & $\begin{array}{l}\text { Putative secreted } \\
\text { protein }\end{array}$ & AAM39862 & 29865 & & 7 & 26 & 74 & 14 \\
\hline \multirow[t]{2}{*}{9} & $\begin{array}{l}\text { UptD outer } \\
\text { membrane protein } \\
\text { with signalP }\end{array}$ & AAM39910 & 17116 & $15-20$ & 13 & 57 & 60 & 14 \\
\hline & $\begin{array}{l}\text { WxcE exported } \\
\text { protein }\end{array}$ & AAM3992I & 20490 & & II & 26 & 54 & 9 \\
\hline \multirow[t]{2}{*}{10} & $\begin{array}{l}\text { Putative exported } \\
\text { protein with signalP }\end{array}$ & AAM40594 & 10647 & $10-15$ & 15 & 117 & - & - \\
\hline & $\begin{array}{l}\text { UptD outer } \\
\text { membrane protein } \\
\text { with signalP }\end{array}$ & AAM399I0 & 17116 & & 6 & 33 & 64 & 16 \\
\hline
\end{tabular}

The section indicates the gel-section excised from the corresponding SDS-PAGE. The values indicated under MW(cal) gives the calculated molecular weight of the identified proteins. The size range relates the excised gel-section with regard to the molecular weight standard on the SDSPAGE. Score (MOWSE-score) and coverage (sequence coverage) relate to the two approaches (ESI-MS/MS or MALDI-TOF-MS) utilized for the identification of the proteins on the SDS-PAGE.

do not contain any or comparable amounts of LPS synthesis intermediates as could be displayed with whole cell LPS preparations. Therefore, it can be proposed that the OMVs are released from sites of the outer membrane that mainly consist of mature LPS.

\section{The OMV proteome does not contain all high abundant} outer membrane proteins

The results from the proteome experiments also clearly indicate that the OMVs originate from the outer membrane. The comparison between the OMV and the most abundant OM proteins only permits a closer look at the outer membrane protein composition, since the OM frac- 
Table 3: Proteins identified in the OMV fraction of cultures grown in XVM2 medium.

\begin{tabular}{|c|c|c|c|c|c|c|c|c|}
\hline Section & Protein & Acc.No. & MW(cal) & $\begin{array}{l}\text { Size } \\
\text { range }\end{array}$ & $\begin{array}{c}\text { Coverage } \\
\text { (ESI-MS/MS) }\end{array}$ & $\begin{array}{l}\text { Score (ESI- } \\
\text { MS/MS) }\end{array}$ & $\begin{array}{l}\text { Coverage } \\
\text { (MALDI) }\end{array}$ & $\begin{array}{c}\text { Score } \\
\text { (MALDI) }\end{array}$ \\
\hline \multirow[t]{4}{*}{ I } & $\begin{array}{l}\text { TonB-dependent } \\
\text { receptor with signalP }\end{array}$ & AAM 42139 & 100858 & $80-150$ & 8 & 311 & 10 & 134 \\
\hline & $\begin{array}{l}\text { XadAI Xanthomonas } \\
\text { adhesion XadA }\end{array}$ & AAM39974 & 220132 & & 7 & 35 & - & - \\
\hline & $\begin{array}{l}\text { HrpA ATP-dependent } \\
\text { RNA helicase }\end{array}$ & AAM42217 & 151602 & & 6 & 32 & 8 & 92 \\
\hline & $\begin{array}{l}\text { RhsD (RhsD protein) } \\
\text { with signalP }\end{array}$ & AAM39448 & 164320 & & 5 & 32 & 7 & 66 \\
\hline \multirow[t]{5}{*}{2} & $\begin{array}{l}\text { FpvA TonB-dependent } \\
\text { outer membrane } \\
\text { ferripyoverdine receptor } \\
\text { with signalP }\end{array}$ & AAM42628 & 81083 & $60-100$ & 9 & 162 & 12 & 118 \\
\hline & $\begin{array}{l}\text { TonB-dependent outer } \\
\text { membrane receptor }\end{array}$ & AAM4I663 & 91909 & & 4 & 61 & 8 & 86 \\
\hline & HrpF (HrpF protein) & AAM405I5 & 98836 & & 6 & 35 & 14 & 84 \\
\hline & $\begin{array}{l}\text { AvrBs2 (avirulence } \\
\text { protein) }\end{array}$ & AAM3937I & 78471 & & 10 & 33 & - & - \\
\hline & $\begin{array}{l}\text { FasD outer membrane } \\
\text { usher protein }\end{array}$ & AAM40677 & 86678 & & 6 & 30 & - & - \\
\hline \multirow[t]{4}{*}{3} & $\begin{array}{l}\text { OmpA family outer } \\
\text { membrane protein with } \\
\text { signalP }\end{array}$ & AAM40245 & 39338 & $40-60$ & 28 & 505 & 21 & 97 \\
\hline & $\begin{array}{l}\text { XynB exported xylan } \\
\text { I,4-beta-xylosidase with } \\
\text { signalP }\end{array}$ & AAM43196 & 58311 & & 5 & 34 & - & - \\
\hline & $\begin{array}{l}\text { UptE Outer membrane } \\
\text { protein with signalP }\end{array}$ & AAM399II & 31591 & & 15 & 33 & 19 & 56 \\
\hline & $\begin{array}{l}\text { AvrBs I avirulence } \\
\text { protein AvrBsI }\end{array}$ & AAM4I388 & 49789 & & 8 & 31 & 13 & 68 \\
\hline \multirow[t]{5}{*}{4} & $\begin{array}{l}\text { OmpA family outer } \\
\text { membrane protein with } \\
\text { signalP }\end{array}$ & AAM40245 & 39338 & $30-40$ & 18 & 113 & 20 & 102 \\
\hline & $\begin{array}{l}\text { Egl exported cellulase } \\
\text { with signalP }\end{array}$ & AAM4279I & 52209 & & 4 & 39 & 9 & 86 \\
\hline & HrcU HrcU protein & AAM40528 & 38694 & & 8 & 30 & 12 & 57 \\
\hline & $\begin{array}{l}\text { HrpX AraC-type } \\
\text { transcriptional regulator } \\
\text { HrpX }\end{array}$ & AAM40465 & 52250 & & 6 & 30 & 18 & 83 \\
\hline & HrcN HrcN protein & AAM40534 & 47759 & & 12 & 29 & 10 & 58 \\
\hline \multirow[t]{2}{*}{5} & $\begin{array}{l}\text { OmpW3 OmpW family } \\
\text { outer membrane protein }\end{array}$ & AAM4279I & 23494 & $25-30$ & 7 & 55 & 7 & 67 \\
\hline & HrpB4 HrpB4 protein & AAM40532 & 22919 & & 4 & 36 & 8 & 59 \\
\hline \multirow[t]{2}{*}{6} & $\begin{array}{l}\text { OmpW3 OmpW family } \\
\text { outer membrane protein }\end{array}$ & AAM4279I & 23494 & $20-25$ & 7 & 48 & 7 & 71 \\
\hline & $\begin{array}{l}\text { XpsH General secretion } \\
\text { pathway protein }\end{array}$ & AAM39979 & 18208 & & 20 & 47 & 17 & 61 \\
\hline \multirow[t]{2}{*}{7} & $\begin{array}{l}\text { Putative exported protein } \\
\text { with signalP }\end{array}$ & AAM40594 & 10647 & $10-20$ & 15 & 245 & 21 & 117 \\
\hline & $\begin{array}{l}\text { UptD outer membrane } \\
\text { protein with signalP }\end{array}$ & AAM39910 & 17116 & & 12 & 27 & 17 & 74 \\
\hline
\end{tabular}

The section indicates the gel-section excised from the corresponding SDS-PAGE. The values indicated under MW(cal) gives the calculated molecular weight of the identified proteins. The size range relates the excised gel-section with regard to the molecular weight standard on the SDSPAGE. Score (MOWSE-score) and coverage (sequence coverage) relate to the two approaches (ESI-MS/MS or MALDI-TOF-MS) utilized for the identification of the proteins on the SDS-PAGE. 
tion is contaminated with inner membrane fragments. Among the most abundant proteins in the OM fraction are 15 outer membrane proteins of which only eight are also present in the OMV proteome. The 11 non-outer membrane proteins are probably loosely associated with either the inner or outer membrane. Interestingly, three of these proteins could also be identified in OMVs. How proteins, that associate with the inner membrane like the signal recognition particle $\mathrm{Ffh}$ and the type-II secretion ATPase end up in the OMV fraction is unclear. Among these non-outer membrane proteins is also the elongation factor TufA. This protein is known to be released or leaked from cultures of numerous bacteria and can therefore be identified in many protein fractions [44]. However, TufA cannot be identified in the OMV protein fraction, indicating that the OMV release from the outer membrane is not an effect of damaged cells. Furthermore, no cytosolic proteins could be identified in the OMV fraction and only one inner membrane protein was present in the OMV sample. This is also an indication that these structures are not products of cell degradation, since we would expect a higher amount of proteins from the inner membrane and of cytosolic origin.

\section{OMVs isolated from M9 and XVM2 medium contain known virulence-associated proteins}

A comparison of the OMV proteomes obtained from different growth conditions revealed a clear influence on the protein composition. Interestingly, the XVM2 medium did not elevate the amount of type-III secretion associated proteins. The only Hrp protein, which was not identified in the M9 sample was HrpXv, which is known to be the regulator of the $h r p$-operon and induced by XVM2 [27]. The adhesin XadA1 was also among the XVM2 induced proteins. It could play a role in the attachment of OMVs to the host surface as it has been described for lipopolysaccharides mimicking the lewis blood antigens present on the surface of OMVs from Helicobacter pylori [28]. The OMVs were also found to contain a vesicle specific core proteome of 7 proteins, which are not among the most abundant OM proteins. This group of proteins mainly consists of virulence associated proteins, which may indicate a putative role of these structures in the pathogenicity of $X c c$. Virulence related proteins are also present in the group of proteins that differ between the cultivation conditions. Unexpectedly, we identified the so-called avirulence proteins AvrBs1 and AvrBs2, which are transported via the type-III secretion system $[29,30]$. Since they do not have trans-membrane segments [31] it can be assumes that they are located in the lumen of the OMVs. Another interesting OMV protein is $\mathrm{HrpF}$, the putative translocon of the type-III secretion system. This protein is proposed to be inserted into the host membrane and serves as attachment site for the type-III conduit [32]. How this protein it transported into the membrane is not entirely clear. One model proposes, that HrpF is transported via the type-III system attached to the tip of the conduit and then pushed through the host membrane $[11,12]$. We offer a model in which HrpF is inserted into the bacterial outer membrane and then released into the medium packed in OMVs. These OMVs could then first attach to the host membrane and then fuse with it to insert HrpF. A similar mechanism has been described for the cytotoxic ClyA protein of enterotoxic E. coli strains. Subunits of this protein are inserted into the bacterial outer membrane and released into vesicles where they multimerise to give rise to the mature pore. Upon fusion of the OMV with the host membrane the cytotoxic pore is inserted and causes lysis of the host cell [16].

We could demonstrate that $X c c$ releases OMVs from its cell surface packed with virulence-associated proteins. Furthermore, a comparison with the most abundant proteins from the outer membrane revealed that some proteins are enriched in the OMV fraction. Further experiments will indicate if OMVs serve as vehicles for virulence factors like HrpF and avirulence proteins into the plant cell.

\section{Conclusion}

The plant pathogenic bacterium Xanthomonas campestris pv. campestris liberates OMVs from its outer membrane during growth. We could demonstrate that these structures not only contain membrane-associated proteins, but also soluble periplasmic proteins, which are probably entrapped in the OMV lumen. A comparison with the most abundant proteins from the outer membrane fraction revealed, that not all high abundant proteins are released with OMVs, suggesting that some proteins are favourably released with these structures. This may be connected to the membrane composition of the OMVs, which differs from whole cell LPS preparations [33]. Nearly half of the proteins that associate with the OMV fraction are involved in virulence either being part of the TTSS, putative virulence factors or cellulytic enzymes. From the results presented in this study we conclude that plant pathogenic bacteria like Xcc can liberate membraneand virulence-associated proteins attached to OMVs into the culture medium. Further experiments will have to prove if OMVs can attach and fuse with plant membranes. This would indicate whether OMVs from plant pathogenic bacteria can deliver virulence-factors as it has been demonstrated for mammalian pathogens.

\section{Methods}

\section{Bacterial Strains and Growth Conditions}

Bacterial cultures of Xanthomonas campestris pv. campestris strain $\mathrm{B} 100$ [34] were cultivated at $30^{\circ} \mathrm{C}$. For inoculation of minimal media $10 \mathrm{~mL}$ TY cultures supplemented with $800 \mu \mathrm{g} \cdot \mathrm{mL}^{-1}$ streptomycin were inoculated with a single colony from fresh culture plates. The Minimal media (M9 
or XVM2) $[13,35,36]$ were always cultivated in 1 L Erlenmeyer flasks filled with $250 \mathrm{~mL}$ of medium and agitated at $150 \mathrm{rpm}$. The starting o.D. (580 nm) of the cultures in minimal media were adjusted to 0.01 .

\section{Isolation of OMVs from culture supernatants}

OMVs were isolated from culture supernatants using a method described by Wai et al. [37] with some modifications. The Xcc B100 cultures were harvested at o.D. (580 $\mathrm{nm})$ 0.8-1.0. Cells were removed by centrifugation $(5000 \cdot g, 30 \mathrm{~min})$ and the supernatant was centrifuged at $10000 \cdot g$ for one hour and subsequently filtered through a $0.2 \mu \mathrm{m}$ filter to remove residual cells. OMVs were recovered from the resulting supernatant by ultracentrifugation at $100000 \cdot \mathrm{g}$ for 6 hours. The pellets were suspended in $100 \mu \mathrm{L}$ rehydration buffer, $1 \%$ (v/v) lauroyl-sarcosine, 1\% triton X-114 for subsequend SDS-PAGE. For electron microscopy, the vesicle pellet was resuspended in $50 \mathrm{mM}$ HEPES buffer ( $\mathrm{pH}-6.8$ ).

\section{Hot-phenol extraction of LPS}

The LPS was extracted as described earlier [38]. Xcc cells were grown for 3 days on TY plates and then washed from the surface with cold $0.9 \%(\mathrm{w} / \mathrm{v}) \mathrm{NaCl}$. The cells were recovered by centrifugation at $10000 \cdot g$ for $30 \mathrm{~min}$ at $4{ }^{\circ} \mathrm{C}$. The resulting pellet was washed twice with cold $0.9 \%(\mathrm{w} /$ v) $\mathrm{NaCl}$. The washed cells were resuspenddd in water, heated to $70^{\circ} \mathrm{C}$ and mixed with an equal volume of preheated water saturated phenol. After $45 \mathrm{~min}$ at $70^{\circ} \mathrm{C}$ the suspension was allowed to cool down on ice for $10 \mathrm{~min}$ prior to centrifugation at $10000 \cdot \mathrm{g}$ for $60 \mathrm{~min}$ at $4^{\circ} \mathrm{C}$. The water phase was dialysed (13000 MWCO, Roth, Karlsruhe Germany) against water untill all phenol was removed. The dialysed LPS was transferred to a $50 \mathrm{ml}$ reaction tube and treated with $5 \mu \mathrm{l} \mathrm{RNase}\left(3 \mathrm{mg} \cdot \mathrm{ml}^{-1}\right)$ and $150 \mu \mathrm{l}$ DNase $\left(3 \mathrm{mg} \cdot \mathrm{ml}^{-1}\right)$ for $3 \mathrm{~h}$ at $37^{\circ} \mathrm{C}$. Remaining proteins were removed with $150 \mu \mathrm{l}$ Proteinase-K $\left(2.5 \mathrm{mg} \cdot \mathrm{ml}^{-1}\right)$ and incubated over night at $37^{\circ} \mathrm{C}$. The LPS extract was lyophilized prior to storage at $-80^{\circ} \mathrm{C}$.

\section{Crude LPS extraction from whole cells and OMVs}

A few Xcc colonies (or OMV suspension) were transferred from a TY plate into $50 \mu \mathrm{l}$ of lysis buffer ( $1 \mathrm{M}$ Tris $\mathrm{pH} 6.8$, $2 \%(\mathrm{w} / \mathrm{v})$ SDS, 4\% (v/v) $\beta$-mercaptoethanol, $10 \%(\mathrm{v} / \mathrm{v})$ glycerol, $0.05 \%$ bromo-phenol-blue) and boiled for 10 min. Then $10 \mu \mathrm{l}$ Proteinase-K was added and incubated at $37^{\circ} \mathrm{C}$ for $60 \mathrm{~min}$. The remaining cells were removed by centrifugation at $13000 \mathrm{rpm}$ in a biofuge and the supernatant was transferred into a fresh reaction tube. The crude LPS extract was mixed with 0.5 volumes of LPS-loading buffer (120 mM Tris pH 6.8, 3\% (w/v) SDS, 9\% (v/v) $\beta$ mercaptoethanol, 30\% (v/v) glycerol, $0.003 \%(\mathrm{w} / \mathrm{v})$ Bromo-Phenol-Blue) prior to gel electrophoresis.

\section{LPS-specific silver stain}

The gels were fixed over night in fixing solution (40\% (v/ v) ethanol, $5(\mathrm{v} / \mathrm{v})$ acetic acid) replaced with oxidation solution $(0.7 \%(\mathrm{w} / \mathrm{v})$ periodic acid in fixing solution) and left to incubate for $5 \mathrm{~min}$. The gels were then washed thrice with deionised water prior a $10 \mathrm{~min}$ incubation step in staining solution (140 ml deionised water, $2.8 \mathrm{ml} 1 \mathrm{~N}$ $\mathrm{NaOH}, 5 \mathrm{ml} 20 \%$ (v/v) $\mathrm{AgNO}_{3}, 2 \mathrm{ml}$ ammonia). After staining, the gels were washed thrice with deionised water and then placed into new containers with developer (50 $\mu \mathrm{l}$ citric acid $\left(100 \mathrm{mg} \cdot \mathrm{ml}^{-1}\right), 50 \mu \mathrm{l}$ formaldehyde in 100 $\mathrm{ml}$ water) an incubated untill bands became visible.

\section{Isolation of outer membrane proteins (OMPs)}

Xcc cells were harvested from $250 \mathrm{~mL}$ of M9 culture by centrifugation at $5000 \cdot \mathrm{g}, 4^{\circ} \mathrm{C}$ for $45 \mathrm{~min}$. The pellet was washed twice with SM buffer $(100 \mathrm{mM} \mathrm{NaCl}, 10 \mathrm{mM}$ $\mathrm{MgSO}_{4}, 20 \mathrm{mM}$ Tris-HCl pH 7.5) and centrifuged as already described. After washing, the pellet was gently resuspended in $50 \mathrm{mM}$ Tris- $\mathrm{HCl} \mathrm{pH}$ 8.0, $1 \mathrm{mM}$ EDTA and sonificated on ice 10 times for 6 seconds with 30 seconds resting time between each period in order to avoid overheating. Intact cells and debris were removed by centrifugation at $5000 \cdot \mathrm{g}$ for $30 \mathrm{~min}$ at $4^{\circ} \mathrm{C}$. The supernatant was then subjected to ultracentrifugation at $100000 \cdot \mathrm{g}$ for 60 min at $4{ }^{\circ} \mathrm{C}$ and the pellet containing proteins was washed in $10 \mathrm{~mL}$ Tris- $\mathrm{HCl}$ and $2 \%(\mathrm{v} / \mathrm{v})$ lauroyl-sarcosine and incubated at $30^{\circ} \mathrm{C}$ for $30 \mathrm{~min}$. The OMPs were collected by centrifugation at $10000 \cdot \mathrm{g}$ for $90 \mathrm{~min}$ at $4^{\circ} \mathrm{C}$. The resulting pellets were dissolved in $100 \mu \mathrm{L}$ of rehydration buffer.

\section{SDS-PAGE Electrophoresis}

The standard SDS-PAGE procedure was used [39]. $50 \mu \mathrm{g}$ of protein sample was loaded onto a $12 \%(\mathrm{w} / \mathrm{v})$ SDSPAGE. The proteins separated by SDS-PAGE were stained with Coomassie Blue. Protein molecular weight standards were obtained from Bio-Rad (Munich, Germany).

\section{In-gel tryptic digest of proteins}

The tryptic digest was performed as described on the Keck home page [45]. Protein sections were excised from SDSPAGE gels and placed into a microtiter plate. $200 \mu \mathrm{L}$ of $50 \%(\mathrm{v} / \mathrm{v})$ acetonitrile (ACN) was added to each sample and incubated while shaking at room temperature (RT) for $5 \mathrm{~min}$. Then this solution was completely removed and $200 \mu \mathrm{L} 50 \mathrm{mM} \mathrm{NH}_{4} \mathrm{HCO}_{3}, 50 \%$ (v/v) ACN was added to the samples and allowed to incubate for $30 \mathrm{~min}$ whilst shaking at RT. After complete removal of this solution the incubation step was repeated with $10 \mathrm{mM} \mathrm{NH}_{4} \mathrm{HCO}_{3}$, $50 \%(\mathrm{v} / \mathrm{v}) \mathrm{ACN}$. Then the samples were allowed to dry completely. Each sample was treated with $80 \mu \mathrm{L}$ of previously activated solution of trypsin and incubated for 5-10 min. $100 \mu \mathrm{L}$ of $10 \mathrm{mM} \mathrm{NH}_{4} \mathrm{HCO}_{3}$ was added to the samples and the samples were incubated at $37^{\circ} \mathrm{C}$ for $20-24$ 
hours. The solution was removed next day and transferred to $1.5 \mathrm{~mL}$ eppendorf tubes pre-washed with $0.1 \%$ TFA. The peptides were extracted by adding $200 \mu \mathrm{L} 0.1 \%$ TFA and $60 \%$ ACN with shaking at RT for $60 \mathrm{~min}$. This step was repeated twice. The samples were then frozen at $80^{\circ} \mathrm{C}$ and lyophilized.

\section{Nano-LC-ESI-MSIMS measurement trypsin digested gel sections}

Electrospray-ionisation-MS was performed on an LCQDECA $^{\text {тм }}$ mass spectrometer (Thermo Fisher Scientific, Waltham, USA) with previously desalting and separation of the tryptic peptides by a NanoLC (Eksigent Technologies, Livermore, USA) run. Dry digests were reconstituted in $10 \mu \mathrm{l}$ of $5 \% \mathrm{ACN}$ in $0.1 \%$ TFA. The LC-system was run with solvents $\mathrm{A}=5 \%$ and $\mathrm{B}=80 \% \mathrm{ACN}$, respectively, in $0.1 \%$ formic acid. The tryptic peptides were subjected to the nano-column $\left(15 \mathrm{~cm} \times 75 \mu \mathrm{m}\right.$ i.d., PepMap ${ }^{\mathrm{TM}} \mathrm{C} 18$, $100 \AA$; Dionex, Idstein, Germany) by an autosampler device. First, for binding and desalting of the peptides a 5min step of $98 \%$ solvent $\mathrm{A} / 2 \%$ solvent $\mathrm{B}$ was run using a nano-flow of $200 \mathrm{nl} \cdot \mathrm{min}^{-1}$. Subsequently, the peptides were eluted from the column applying a gradient with increasing acetonitrile concentration $(2 \%-50 \%$ 'B' in 40 min) with the same flow rate $\left(200 \mathrm{nl} \cdot \mathrm{min}^{-1}\right)$. The separated peptides were transferred via a fused silica capillary (50 $\mu \mathrm{m}$ i.d.) to the nanospray needle (15 $\mu \mathrm{m}$ tip, New Objective, MA, USA) of the LCQ Deca ion source. Ionization and sample uptake by the mass spectrometer occurred with a spray/needle voltage of $1.3 \mathrm{kV}$ and a capillary voltage of $30 \mathrm{~V}$ at $165^{\circ} \mathrm{C}$. Via a MS to MS/MS switch mode (zoom scan + dependent scan) relevant precursor ions were detected automatically for MS/MS-acquisition using the X-calibur software ${ }^{\mathrm{TM}}$, (Thermo Fisher Scientific). Peptide fragmentation was initiated by collision energy in the ion-trap MS. For subsequent database search the entire MS/MS-spectra per run were converted into dta-files using the Bioworks 3.0 software (Thermo Fisher Scientific). The identification of the proteins was carried out using the Mascot software (Matrix Science, London, UK), which is implemented on our local server. The Xcc database generated from the Xanthomonas campestris pv. campestris B100 sequencing project [6] was used to perform the Mascotaided search. The following parameters were used for the MS/MS ion search: enzyme: trypsin; missed cleavage: 2; peptide tolerance $150 \mathrm{ppm} ; \mathrm{M} / \mathrm{MS}$ tolerance: $100 \mathrm{ppm}$; peptide charge $+1,+2$ and +3 ; ion type: monoisotopic. For comparability, the accession numbers were taken from the Xcc strain ATCC 33913 database [3] as they are used by the expasy [46] internet resource.

\section{MALDI-TOF-MS measurements}

Protein bands were excised from Coomassie stained acrylamide gels and digested with trypsin as already described. The supernatants of the in-gel digests were mixed with the same volume of a solution containing water, acetonitrile and TFA (67:33:0.1), which was saturated with $\alpha$-cyano-4hydroxy cinnamic acid. These solutions were spotted on to an Anchor-Chip ${ }^{\text {тм }}$ (Bruker, Bremen) MALDI target and left to dry at room temperature. This spotting procedure was repeated thrice each time applying $1 \mu \mathrm{l}$ of sample. The corresponding peptide mass fingerprints (PMF) were measured with an Ultraflex ${ }^{\mathrm{TM}}$ II (Bruker, Bremen) MALDITOF-MS using the manufacturers settings for peptides measurements. The Mascot software was used for queries in our Xcc database (described above). The following parameters were chosen for the query: enzyme: trypsin; missed cleavages: 1; peptide tolerance: 150 ppm; mass values: $\mathrm{MH}^{+}$mono isotopic.

\section{$N$-terminal secretion signal-peptide prediction using the Signal $P$ software}

The Signal P software [40] was used to search the genome sequence of Xcc ATCC 33913 for proteins with putative Nterminal secretion signals. The following parameters were set to produce most reliable results: (a) organism type: Gram-negative, (b) only the first $60 \mathrm{~N}$-terminal amino acids were submitted, (c) both, Neural Network and Hidden Markov Model algorithms must predict the same cleavage site, (d) the prediction score had to be higher than 0.98 .

\section{Electron Microscopy}

Vesicles obtained by ultracentrifugation $(100,000 \times \mathrm{g}, 6$ hours) were resuspended in $50 \mu \mathrm{L}$ of $50 \mathrm{mM}$ HEPES buffer (pH 6.8). Nickel grids supported with formvar coating were used for electron microscopy. For this purpose, glass slides were cleaned with ethanol and then dipped in a formvar solution containing $0.6 \%$ formvar in chloroform. They were allowed to dry and then scratched carefully from the sides to loosen the film. The slide was lowered into the water at a 30 degree angle such that the formvar coating floats off onto the surface of the water. Using the forceps, the grids were placed in rows on the surface of the formvar with the shiny side facing up until the entire formvar sheet was covered with grids. The grids with formvar film adhering to them were picked using paraffin wax from the water surface and subsequently coated with carbon after placing them on a Whatman filter paper to dry. These carbon coated formvar grids were then used for observing outer membrane vesicles. $20 \mu \mathrm{L}$ of purified OMVs were placed on glow-discharged carbon-coated formvar grids, which were subsequently fixed with $1 \%(\mathrm{v} /$ v) glutaraldehyde, rinsed three times with water and visualized by staining with $1 \%(\mathrm{w} / \mathrm{v})$ uranyl acetate. The size of the OMVs was determined by comparing with the width of the tobacco mosaic virus. 


\section{Electron Microscopy of OMVs with gold-labelled anti-Xcc} antibodies

Immunogold Electron Microscopy (IEM) was performed using fresh cultures of Xcc and OMVs prepared as described above. For IEM, carbon-coated formvar grids were used and the surface of the grid was prepared by covering it briefly with a $0.1 \%(\mathrm{w} / \mathrm{v})$ solution of poly-L-lysine in water [41]. The surface of the grids was washed thoroughly with water and subsequently placed on a drop of bacterial culture or OMV suspension. The cells or OMVs were allowed to settle in order to adhere to the grids. The adhered bacteria or vesicles were preincubated for $30 \mathrm{~min}$ at RT with blocking buffer ( $0.1 \%$ normal goat serum) followed by three washing steps with phosphat saline buffer containing $0.1 \%(\mathrm{w} / \mathrm{v})$ bovine serum albumin (BSA) (Sigma-Aldrich, Steinheim, Germany). The samples were subsequently incubated for 1 hour at RT on droplets containing an anti-Xcc B100 antibody (Eurogentec, Seraing, Belgium) [22] in a 1:50 dilution that is able to specifically recognise Xanthomonas LPS in the OMVs. Non-bound antibody was removed by washing the grids twice for 10 min on PBS containing $0.1 \%(\mathrm{w} / \mathrm{v})$ BSA. The primary antibody was detected using goat-anti-rabbit antibody (Aurion, Wageningen, NL) coupled to $10 \mathrm{~nm}$ gold particles. The conjugates were diluted 1:20 in PBS containing $0.1 \%(\mathrm{w} / \mathrm{v})$ BSA and incubated for $30 \mathrm{~min}$ at RT. Unbound conjugate was removed by a sequence of washing steps (twice with PBS containing 0.1\% (w/v) BSA for 5 min; once with PBS for $3 \mathrm{~min}$ and a final wash with water for $3 \mathrm{~min}$ ) at RT. Before negative staining with $1 \%$ $(\mathrm{w} / \mathrm{v})$ uranyl acetate, the grids were washed rapidly on four droplets of water. The preparations were analysed with Philips CM 100 (Philips Electronics, Eindhoven, NL) and Zeiss EM109 (Carl Zeiss Inc. Oberkochen, Germany).

\section{Authors' contributions}

VKS carried out the electron microscopy, the proteome study and was involved in drafting of the manuscript. FJV was responsible for the annotation of the Xcc strain B100 genome, which was used in the proteome study. KN was involved in the design of the study and helped to draft the manuscript. SAW designed the study and was involved in drafting the manuscript. All authors have read the final version of the manuscript.

\section{Additional material}

\section{Additional file 1}

Tables 4-6.

Click here for file

[http://www.biomedcentral.com/content/supplementary/14712180-8-87-S1.doc]

\section{Acknowledgements}

We want to thank the BMBF for funding this project, which is part of the Kompetenznetzwerk Genomik Plus. We also want to thank the DFG Initiative Bioinformatic and Genome Research.

\section{References}

I. Dye DW, Bradbury JF, Goto M, Hayward AC, Lelliott RA, Schroth $M N$ : International standards for naming pathovars of phytopathogenic bacteria and a list of pathovar names and pathotype strains. Rev Plant Pathol 1980, 59:I 53-I68.

2. Swings JG, Civerolo EL, Eds: Xanthomonas London: Chapman \& Hall; 1993.

3. da Silva ACR, Ferro JA, Reinach FC, Farah CS, Furlan LR, Quaggio RB, Monteiro-Vitorello CB, Van Sluys MA, Almeida NF, Alves LMC, do Amaral AM, Bertolini MC, Camargo LEA, Camarotte G, Cannavan F, Cardozo J, Chambergo F, Ciapina LP, Cicarelli RMB, Coutinho LL, Cursino-Santos JR, El-Dorry H, Faria JB, Ferreira AJS, Ferreira RCC, Ferro MIT, Formighieri EF, Franco MC, Greggio CC, Gruber A, Katsuyama AM, Kishi LT, Leite RP, Lemos GM, Lemos MVF, Locali EC, Machado MA, Madeira AMBN, Martinez-Rossi NM, Martins EC, Meidanis J, Menck CFM, Miyaki CY, Moon DH, Moreira LM, Novo MTM, Okura VK, Oliveira MC, Oliveira VR, Pereira HA, Rossi A, Sena JAD, Silva C, de Souza RF, Spinola LAF, Takita MA, Tamura RE, Teixeira EC, Tezza RID, Trindade dos Santos M, Truffi D, Tsai SM, White FF, Setubal JC, Kitajima JP: Comparison of the genomes of two Xanthomonas pathogens with differing host specificities. Nature 2002, 41 7:459-463.

4. Lee BM, Park YJ, Park DS, Kang HW, Kim JG, Song ES, Park IC, Yoon UH, Hahn JH, Koo BS, Lee GB, Kim H, Park HS, Yoon KO, Kim JH, Jung $\mathrm{CH}$, Koh $\mathrm{NH}$, Seo JS, Go SJ: The genome sequence of $X$ anthomonas oryzae pathovar oryzae KACCI the bacterial blight pathogen of rice. Nucleic Acids Research 2005, 33:577-586.

5. Thieme F, Koebnik R, Bekel T, Berger C, Boch J, Büttner D, Caldana C, Gaigalat L, Goesmann A, Kay S, Kirchner O, Lanz C, Linke B, McHardy AC, Meyer F, Mittenhuber G, Nies DH, Niesbach-Klösgen U, Patschkowski T, Rückert C, Rupp O, Schneiker S, Schuster SC, Vorhölter FJ, Weber E, Pühler A, Bonas U, Bartels D, Kaiser O: Insights into genome plasticity and pathogenicity of the plant pathogenic bacterium Xanthomonas campestris pv. vesicatoria revealed by the complete genome sequence. J Bacteriol 2005, I 87:7254-7266.

6. Vorhölter FJ, Schneiker S, Goesmann A, Krause L, Bekel T, Kaiser O, Linke B, Patschkowski T, Rückert C, Schmid J, Sidhu VK, Sieber V, Tauch A, Watt SA, Weisshaar B, Becker A, Niehaus K, Pühler A: The genome of Xanthomonas campestris pv. campestris BI00 and its use for the reconstruction of metabolic pathways involved in xanthan biosynthesis. J Biotechnol in press.

7. Qian W, Jia Y, Ren SX, He YQ, Feng JX, Lu LF, Sun Q, Ying G, Tang DJ, Tang H, Wu W, Hao P, Wang L, Jiang BL, Zeng S, Gu WY, Lu G, Rong L, Tian Y, Yao Z, Fu G, Chen B, Fang R, Qiang B, Chen Z, Zhao GP, Tang JL, He Chaozu: Comparative and functional genomic analyses of the pathogenicity of phytopathogen Xanthomonas campestris pv. campestris. Genome Res 2005, I 5:757-67.

8. Lahaye T, Bonas U: Molecular secrets of bacterial type III effector proteins. Trends Plant Sci 200I, 6:9-485.

9. Mudgett MB: New insights to the function of phytopathogenic bacterial type III effectors in plants. Annual Reviews in Plant Biology 2005, 56:509-531.

10. Francis MS, Wolf-Watz H, Forsberg A: Regulation of type III secretion systems. Curr Opin Microbiol 2002, 5: I66-I72.

II. Büttner D, Bonas U: Port of entry-the type III secretion translocon. Trends in Microbiology 2002, 10:186-192.

12. Büttner D, Nennstiel D, Klüsener B, Bonas U: Functional analysis of HrpF, a putative type III translocon protein from Xanthomonas campestris pv. vesicatoria. J Bacteriol 2002, I 84:2389-2398.

13. Watt SA, Wilke A, Patschkowski T, Niehaus K: Comprehensive analysis of the extracellular proteins from Xanthomonas campestris pv. campestris B I00. Proteomics 2005, 5:I53-167.

14. Talker-Huiber D, Jose J, Glieder A, Pressnig M, Stubenrauch G, Schwab H: Esterase EstE from Xanthomonas vesicatoria (Xv_EstE) is an outer membrane protein capable of hydrolyzing long-chain polar esters. Applied Microbiology and Biotechnology 2003, 6 I:479-487. 
15. Dow JM, Davies HA, Daniels M: A metalloprotease from Xanthomonas campestris that specifically degrades proline hydroxyproline-rich glycoproteins of the plant extracellular matrix. J Mo Plant-Microbe Interact 1998, I I:1085-1093.

16. Wai SN, Lindmark B, Soderblom T, Takade A, Westermark M, Oscarsson J, Jass J, Richter-Dahlfors A, Mizunoe Y, Uhlin B: Vesiclemediated export and assembly of pore-forming oligomers of the enterobacterial ClyA cytotoxin. Cell 2003, I I 5:25-35.

17. Shoberg RJ, Thomas DD: Borrelia burgdorferi vesicle production occurs via a mechanism independent of immunoglobulin M involvement. Infect Immun 1993, 61:3892-3900.

18. Patrick S, McKenna JP, Ohagan S, Dermott EA: A comparison of the haemagglutinating and enzymic activities of Bacteroides fragilis whole cells and outer membrane vesicles. Microbial Pathogenesis 1996, 20:191-202.

19. Beveridge TJ: Structures of gram-negative cell walls and their derived membrane vesicles. J Bacteriol 1999, 181:4725-4733.

20. Mashburn LM, Whiteley M: Membrane vesicles traffic signals and facilitate group activities in a prokaryote. Nature 2005, 437:422-425.

21. Dorward DW, Garon CF, Judd RC: Export and intercellular transfer of DNA via membrane blebs of Neisseria gonorrhoeae. J Bacteriol | 989, I 7 I:2499-2505.

22. Meyer A: Untersuchungen zur Beteiligung des Lipopolysaccharids des phytopathogenen Bakteriums Xanthomonas campestris pv. campestris in der Elicitierung von Pflanzenabwehr am Beispiel des oxidative burst in Zellkulturen des Nichtwirts Tabak (Nicotiana tabacum). In PhD thesis Bielefeld University, Chair of Genetics; 200 I.

23. Kadurugamuwa JL, Beveridge TJ: Natural release of virulence factors in membrane vesicles by Pseudomonas aeruginosa and the effect of aminoglycoside antibiotics on their release. Antimicrob Chemother 1997, 40:615-621.

24. Kadurugamuwa JL, Beveridge T): Virulence factors are released from Pseudomonas aeruginosa in association with membrane vesicles during normal growth and exposure to gentamicin: a novel mechanism of enzyme secretion. J Bacteriol 1995, 177:3998-4008.

25. Li Z, Clarke AJ, Beveridge TJ: Gram-negative bacteria produce membrane vesicles which are capable of killing other bacteria. J Bac 1998, 180:5478-5483.

26. Fiocca R, Necchi V, Sommi P, Ricci V, Telford J, Cover TL, Solcia E: Release of Helicobacter pilori vacuolating cytotoxin by both a specific secretion pathway and budding of outer membrane vesicles. Uptake of released toxin and vesicles by gastric epithelium. J Pathol 1999, 188:220-206.

27. Wengelnik K, Bonas U: HrpXv, an AraC-type regulator, activates expression of five of the six loci in the hrp cluster of Xanthomonas campestris pv. vesicatoria. J Bacteriol 1996:3462-3469

28. Appelmelk B], Simoons-Smit I, Negrini R, Moran AP, Aspinall GO, Forte JG, De Vries T, Quan H, Verboom T, Maaskant JJ, Gnhiara P, Kuipers EJ, Bloemena E, Tadema TM, Townsend RR, Tyagarajan $K$, Crothers JM, Monteiro MA, Savio A, De Graaff J, McGhee JR: Potential role of molecular mimicry between Helicobacter pylori lipopolysaccharide and host Lewis blood group antigens in autoimmunity. Infect Immun 1996, 64:203I-2040.

29. Mudgett MB, Chesnokova O, Dahlbeck D, Clark ET, Rossie O, Bonas $U$, Staskawizc BJ: Molecular signals required for type III secretion and translocation of the Xanthomonas campestris AvrBs2 protein to pepper plants. Proc Natl Acad Sci USA 2000, 97:13324-13329.

30. Casper-Lindley C, Dahlbeck D, Clark ET, Staskawicz BJ: Direct biochemical evidence for type III secretion-dependent translocation of the AvrBs2 effector protein into plant cells. Proc Nat Acad Sci USA 2002, 99:8336-834I.

31. Glasgow J, Sonnhammer EL, von Heijne G, Krogh A, Eds: A hidden Markov model for predicting transmembrane helices in protein sequences. In Sixth Int Conf On Intelligent Systems for Mol Biol AAAI Press; 1998:175-182.

32. Büttner D, Bonas U: Getting across-bacterial type III effector proteins on their way to the plant cell. The EMBO Journal 2002, 21:5313-5322

33. Nguyen TT, Saxena A, Beveridge TJ: Effect of surface lipopolysaccharide on the nature of membrane vesicles liberated from the Gram-negative bacterium Pseudomonas aeruginosa. Electron Microsc (Tokyo) 2003, 52:465-469.

34. Hötte B, Rath-Arnold I, Pühler A, Simon R: Cloning and analysis of a 35.3-kilobase DNA region involved in exopolysaccharide production by Xanthomonas campestris pv. campestris. J Bacteriol 1990, 172:2804-2807.

35. Wiggerich HG, Klauke B, Köplin R, Priefer UB, Pühler A: Unusual structure of the tonB-exb DNA region of Xanthomonas campestris pv. campestris: ton $B$, exbB, and exbDI are essential for ferric iron uptake, but exbD2 is not. J Bacteriol 1997, 179:7103-7II0.

36. Schulte R, Bonas U: Expression of the Xanthomonas campestris pv. vesicatoria hrp gene cluster, which determines pathogenicity and hypersensitivity on pepper and tomato, is plant inducible. J Bacteriol 1992, 174:815-823.

37. Wai SN, Takade A, Amako K: The release of outer membrane vesicles from the strains of enterotoxigenic Escherichia coli. Microbiol Immunol 1995, 39:45|-456.

38. Carlson RW, Yadav M: Isolation and partial characterization of the extracellular polysaccharides and lipopolysaccharides from fast-growing Rhizobium japonicum USDA 205 and its Nod- mutant, HC205, which lacks the symbiotic plasmid. Appl Environ Microbiol 1985, 50:1219-1224.

39. Laemmli UK: Cleavage of structural proteins during the assembly of the head of bacteriophage T4. Nature 1970 , 227:680-685.

40. Nielsen H, Engelbrecht J, Brunak S, von Heijne G: Identification of prokaryotic and eukaryotic signal peptides and prediction of their cleavage sites. Prot Engeneer 1997, 10:1-6.

41. Mazia D, Schatten G, Sale W: Adhesion of cells to surfaces coated with polylysine. Applications to electron microscopy. J Cell Biol 1975, 66:198-200.

42. Balcerzak M, Malinowska A, Thouverey C, Skrecka A, Dadlez M, Buchet R, Pikula S: Protome analysis of matrix vesicles isolated from femurs of chicken embryo. Protomics 2008, 8: 192-205.

43. Wu J, Liu W, Sousa E, Qiu YC, Pittman DI, Maganti V, Feldman J, Gill D, Lu ZJ, Dorner AJ, Schaub R, Tan XY: Proteomic identification of endothelial proteins isolated in situ from atherosclerotic aorta via systemic perfusion. J Prot Res 2007, 6:4728-4736.

44. Rinas U, Hoffmann F: Selective leakage of host-cell proteins during high-cell-density cultivation of recombinant and nonrecombinant Escherichia coli. Biotechnol Prog 2004, 20:679-687.

45. WM Keck Foundation Biotechnology ResourceLaboratory [http://info.med.yale.edu/wmkeck/prochem/geldig3.htm]

46. Swiss-Prot Protein knowledgebase [http://info.med.yale.edu/ wmkeck/prochem/geldig3.htm]
Publish with Bio Med Central and every scientist can read your work free of charge

"BioMed Central will be the most significant development for disseminating the results of biomedical research in our lifetime. "

Sir Paul Nurse, Cancer Research UK

Your research papers will be:

- available free of charge to the entire biomedical community

- peer reviewed and published immediately upon acceptance

- cited in PubMed and archived on PubMed Central

- yours - you keep the copyright
BioMedcentral 